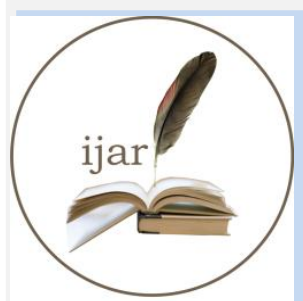

ISSN NO. 2320-5407

\section{Journal Homepage: - www.journalijar.com INTERNATIONAL JOURNAL OF ADVANCED RESEARCH (IJAR)}

Article DOI: $10.21474 / \mathrm{IJAR} 01 / 1427$

DOI URL: http://dx.doi.org/10.21474/IJAR01/1427
INTERNATIONAL JOURNAL OF ADVANCED RESEARCH (JJAR)

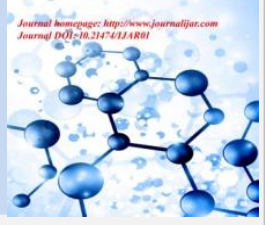

RESEARCH ARTICLE

\title{
INSECT PESTS OF FORESTRY PLANTS AND THEIR MANAGEMENT.
}

Meeta Sharma

Arid Forest Research Institute, Jodhpur (Rajasthan)-342005.

\section{Manuscript Info}

Manuscript History

Received: 12 June 2016

Final Accepted: 19 July 2016

Published: August 2016

Key words:-

Forest, Bruchid, Parasitoid.

\section{Abstract}

Indian arid zone covers 31.7 million ha hot desert and 0.78 million ha cold desert, which is about 12 percent of the country's total geographical area. The mean annual rainfall in the region varies from $100 \mathrm{~mm}$ in the north- western sector of Jaisalmer to $550 \mathrm{~mm}$ in eastern districts of Rajasthan, Gujarat and Haryana. The rainfall is highly erratic having 65 percent coefficient of variability. The vegetation in the Indian arid zone is very sparse, scanty and thorny. However, the forests and trees like many other plants, suffer from attack by insect pests and diseases which cause a lot of damage, resulting in poor tree growth, poor timber quality, and in some cases, complete destruction and reduction of forest cover in Indian arid zone also. Thus, trees and forests need to be protected from these agents of destruction. With the ever increasing human and livestock population, the amount of forest per capita is declining particularly in the less industrialized or developing areas of the world. It is estimated that the land under forest in developing countries is about 2100 million hectares, or more than half of the forested land on earth. Considerable effort is needed therefore to increase the productivity of the existing forests and to afforest suitable areas. Diseases and insect pests constitute the major biological determinants of forest productivity in the natural forests and particularly in plantations, thus offsetting the effort in increasing wood production to meet the growing needs of an increasing population.

The trees selected for seed production can have individual branches covered with sleeves or pollination bags made from woven glass fibre material to exclude the pest species. Insecticides like Endosulphan and Tetrachlorvinphos are effective against bruchids. Some parasites and predators can be successfully used to control the bruchids Parasites attack on egg, larvae and pupal stages. Bruchid eggs, because of their position on the out side of a pod, are easily located by parasitoids. Uscana sumifumipennis has been reported be a group of egg parasitoids associated with bruchids. Bruchids fall to complete their life cycle in presence of mites (Acarina) of the genus Pymotes. They feed on egg, larvae pupae and adults of bruchids. Pymotis boylei is most probably the species which attacks on bruchids. 


\section{Introduction:-}

The arid regions of India cover an area of $317,090 \mathrm{~km}^{2}$ and lies a $24^{0}-29^{0}$ latitude and $70^{0}-76^{0}$ longitude. The region is spread over seven states, viz., Rajasthan, Gujarat, Punjab, Harayana, Maharashtra, Karanataka and Andhra Pradesh, the north-western part of the country constituting almost $90 \%$ of the total arid zone area. Thus Rajasthan state alone accounts for $60 \%$ of the arid zone of India. The mean annual rainfall varies from $100 \mathrm{~mm}$ in the northwest to $450 \mathrm{~mm}$ in the eastern part of Rajasthan. Over $9 \%$ of the total Annual rainfall occurs between June and September. The mean maximum temperature during the summer is $40^{\circ} \mathrm{C}$. The mean winter season temperature varies from $14^{0} \mathrm{C}$ to $16^{0} \mathrm{C}$.

The potential evapotranspiration during summer is 7 to $9 \mathrm{~mm} / \mathrm{day}$, during the monsoon 5.3 to $6.4 \mathrm{~mm} / \mathrm{day}$ and in winter ranges from 1.8 to $2.9 \mathrm{~mm} /$ day. Thus, the evapotranspiration far exceeds precipitation throughout most of the year. High wind velocity is characteristics during summer and monsoon season throughout the north-western arid zone. The wind speeds are minimum during the post monsoon period. In arid semi-arid areas, moisture availability is a major limiting factor for successful establishment and early growth of trees. On sloping land the survival and establishment of the seedlings is particularly difficult because the little water available from rainfall tend to run off down the slope. Planting in sunken pits and triangular ( $\mathrm{V}$-shaped) and semi-circular bunds might improve the survival and growth rates of seedlings over normal planting pits under these conditions, due to increase water availability, reduced wind speed of reduced evapotranspiration.

Forests and trees like many other plants, suffer from attack by insect pests and diseases which cause a lot of damage, resulting in poor tree growth, poor timber quality, and in some cases, complete destruction and reduction of forest cover. Thus, trees and forests need to be protected from these agents of destruction. With the ever increasing human and livestock population, the amount of forest per capita is declining particularly in the less industrialized or developing areas of the world. It is estimated that the land under forest in developing countries is about 2100 million hectares, or more than half of the forested land on earth. Considerable effort is needed therefore to increase the productivity of the existing forests and to afforest suitable areas. Diseases and insect pests constitute the major biological determinants of forest productivity in the natural forests and particularly in plantations, thus offsetting the effort in increasing wood production to meet the growing needs of an increasing population.

Indian arid zone covers 31.7 million ha hot desert and 0.78 million ha cold desert, which is about 12 percent of the country's total geographical area. The mean annual rainfall in the region varies from $100 \mathrm{~mm}$ in the north- western sector of Jaisalmer to $550 \mathrm{~mm}$ in eastern districts of Rajasthan, Gujarat and Haryana. The rainfall is highly erratic having 65 percent coefficient of variability. Drought and famines are quiet frequent rendering crop production a risky enterprise. Other climatic features, adversely affecting the plant growth are: (i) wide variation in temperature (minimum $0^{\circ} \mathrm{C}$ in winter and maximum reaching $50^{\circ} \mathrm{C}$ in summer), (ii) strong winds (with average velocity $20-30$ $\mathrm{Km} / \mathrm{hrs}$ and reaching as high as $130 \mathrm{Km}$ per hour occasionally), (iii) high potential evapotranspiration (7-13mm/day in summer) and (iv) soil sandy, infertile, underlain with hard pan, at places having duny and rocky topography. Forestry scenario of the region is very grim, with only $2.61 \%$ forest area. Sustained forestry production of forest resources in arid and semi- arid areas of India is of vital importance for the life support systems of the country. Arid and semi-arid tracts of India cover around 1.26 million $\mathrm{Km}^{2}$., which accounts for $38 \%$ of the country area. Khejri (Prosopis cineraria) trees in the farmers fields is a common feature of arid and semi-arid landscapes. In fact, an adequate tree covers forms the basis of sustained agricultural, horticultural and forestry production in the inhospitable environmental conditions of the arid and semi-arid areas through conservation of land resources. Continuing over-exploitation of natural vegetation by ever increasing human and livestock populations has resulted in extensive deforestation with consequent negative impacts on production forestry.

Studies were taken up at Forest nurseries, young plantations and on the experimental fields of the Arid Forest Research Institute. Observations were also made on the young and mature trees of P. cineraria, P. juliflora, T. undulata and $A$. indica trees, scatteredly found in the farmers fields, AFRI experimental areas in and adjacent Jodhpur on pest spectrum and their natural enemies. Extensive surveys have been made in 138 localities, selected in Nagaur, Siker, Churu, and Jhunjhunu districts to study the causes responsible for the large-scale mortality of Khejri trees. Data were recorded on the various biotic and abiotic factors in the farmer's fields. The insect pest specimens were collected and preserved either as dry and pinned specimens or as wet collections in $70 \%$ alcohol. Identifications of insects were obtained through from Indian Agricultural Research Institute, New Delhi; Common Wealth Institute of Entomology, London; Zoological Survey of India, Calcutta and also by comparing the specimens at Forest Research Institute, Dehra Dun. Different standard methodologies were adopted in carrying out 
experiments on the biology and efficacy of parasites and predators of important insect pests of these tree species.

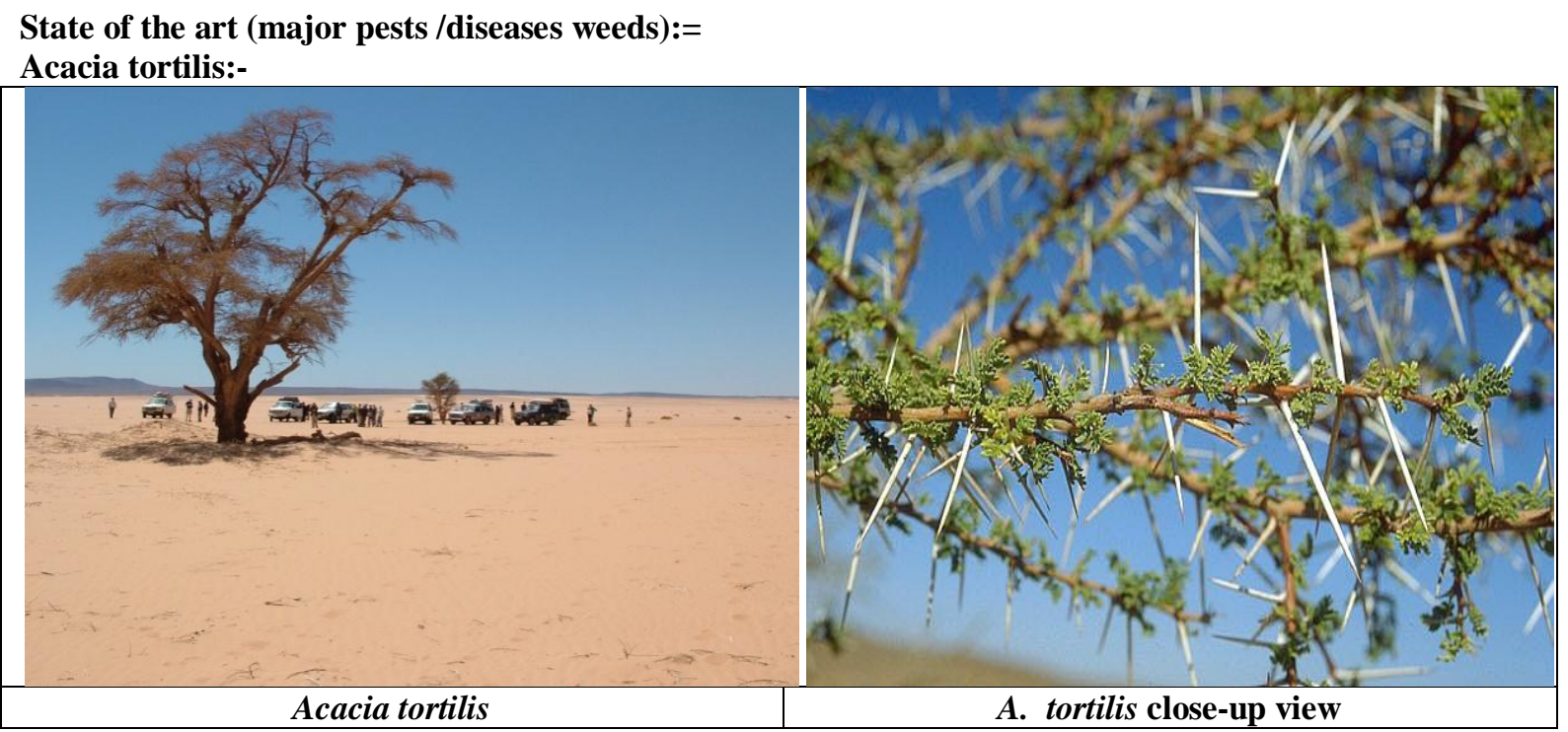

Acacia tortilis, is native of Sudan, Ethiopia, Yemen, Somalia, part of Kenya, Tanzania, Arabia and Southern Israel. It is usually a medium size tree of 4 to $12 \mathrm{~m}$ height, sometimes a shrub or bush $1.5-18 \mathrm{~m}$ high, occasionally of $21 \mathrm{~m}$. Bark on trunk usually rough and fissured, grey to black brown. Crown usually flat and spreading (parasol type) but sometimes (especially in sub sp. raddiana) rounded. Young branchlets densely to sparsely pubescent or glabrous to subglabrous. Spines paired; some short and hooked, up to about $5 \mathrm{~mm}$ long, others long straight, slender, whitish, $1.2-8(-10) \mathrm{cm}$ long, never enlarged or inflated. Petiole usually with a gland. Pinnae 2-10, occasionally to 14 pairs on a short rachis up to 2 (-4) cm long, usually glandular between the top 1-3 and lowest 1-2 pairs of pinnae. Leaflets 620 pairs per pinna, glabrous to densely pubescent, 0.5-2.5(-6) $\mathrm{mm}$ long, 0.2-1(-1.5) $\mathrm{mm}$ wide. Flowers white or yellowish-white, scented, in round fluffy heads $0.5-1.1 \mathrm{~cm}$ in diameter, on axillary peduncles $0.4-2.5 \mathrm{~cm}$ long. Pods variable indehiscent or slowly dehiscent, contorted or spirally twisted, very rarely and abnormally (Kenya) pods straight or nearly so, glabrous, pubescent or tomentellous, rarely with spreading hairs. Seeds oblique or parallel to long axis of pods.

In general, A. tortilis, a member of family Mimosoideae is very distinctive and easily recognized with the characteristics mixture of long straight spines and shorter hooked ones combined with spirally twisted or contorted crown has given it the popular name of Umbrella Urorn; however the foliage is smaller than in many acacias, and the whitish flowers in small round heads are also characteristic, though this is a feature shared with other Acacia species. Under Indian arid conditions this species starts flowering and fruiting at 3 years of age. Flower buds appear in the first week of May and fruit setting commences from mid July. Fruits ripen during the period November to February. On an average, annually a tree yields 4 to $6 \mathrm{~kg}$ seeds at 6 to 8 years of age. Seeds of this species which are light brown in colour resemble those of Acacia nilotica sub sp. indica (babool) in size and the weight is approximately $85 \mathrm{~g} / 1000$ seeds.

\section{Insect pests:-}

Numerous insect pests and diseases attack Acacia tortilis right from seed collection to plantation stage. Some important insect pests of A. tortilis and their control measures are being described.

Four main groups of insects feed upon the seeds of Acacia tortilis in arid and semi-arid zones. These are Coleoptera (beetles), Hemiptera (plant Bugs) Lepidoptera (moth and butterflies) and Hymenoptera (phytophagus wasps). The Coleoptera (beetles) is the most important group of insects causing damage. The larvae stage of Coleoptera, Lepidoptera and Hymenoptera cause damage by boring into the seed from an egg laid on the pod or in the pod tissue. Hemiptera (plant bugs) feed externally in the larvae and adult stages by inserting sucking mouth parts into pod tissue. The Bruchidae beetles exert tremendous influence on the leguminous trees in tropics. Bruchidae are small insects. They are oval-shaped but appear slightly truncated at both ends. Most species have large compound 
eyes with a deep U-shaped cleft opening towards the front. The antennae arise from this cleft. Most bruchids have flattened scale like hairs covering the thorax and elytra. Majority of bruchid species infesting the tree, lay eggs on the surface of the developing pods. Egg development takes 5-10 days from ovi-position. The larva's first priority on emergence is to gain access to the seed. Larvae first form a tunnel within the seed and then enlarge this to make a cell. During the period of growth, which may take 3-4 weeks or as many months, depending on prevailing climatic conditions, the larvae moult 4 times and then pupate. Before this happens preparation is made for the emergence of the adults. The area of the cell nearest to the out-side is cleared and enlarged and only a thin layer of testa is left which forms a circular window of semi-translucent material. On emergence the adults bite their way out leaving circular holes.

\section{Control measures:-}

The trees selected for seed production can have individual branches covered with sleeves or pollination bags made from woven glass fibre material to exclude the pest species. Insecticides like Endosulphan and Tetrachlorvinphos are effective against bruchids. Some parasites and predators can be successfully used to control the bruchids Parasites attack on egg, larvae and pupal stages. Bruchid eggs, because of their position on the out side of a pod, are easily located by parasitoids. Uscana sumifumipennis has been reported be a group of egg parasitoids associated with bruchids. Bruchids fall to complete their life cycle in presence of mites (Acarina) of the genus Pymotes. They feed on egg, larvae pupae and adults of bruchids. Pymotis boylei is most probably the species which attacks on bruchids.

\section{Prosopis cineraia:-}

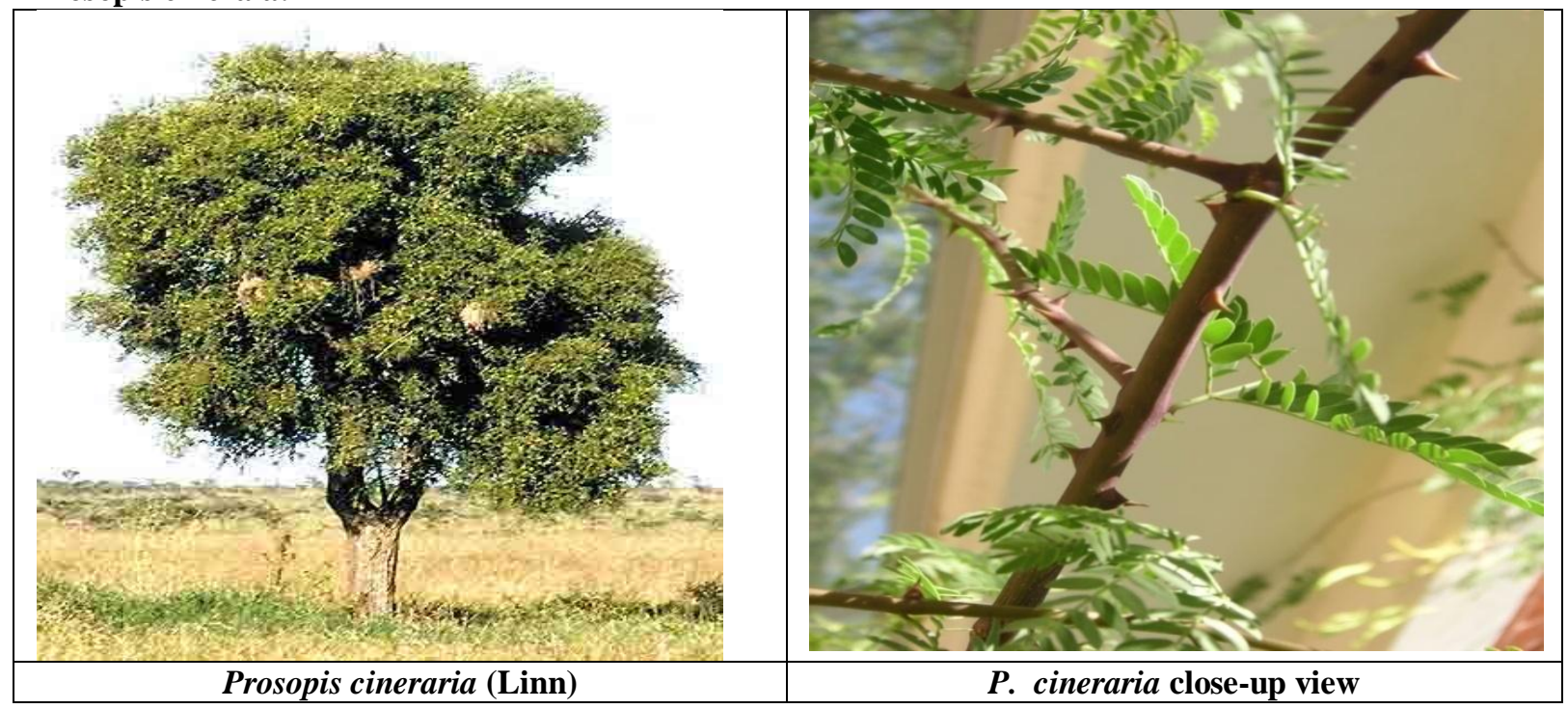

Prosopis cineraria (Linn) is commonly known as 'Khejri' in Rajasthan. Naturally occurring khejri has been reported from Afghanistan, Iran, Pakistan (Baluchistan and Sind) and India (Rajasthan, Delhi, Haryana, Gujarat) (Puri et al., 1964). P. cineraria is the king tree of Indian arid region, revered for its range of products and services rendered to desert inhabitants. Whereas, Tecomella undulata (Sm) Seem, generally known as 'Rohida' or 'Marwar teak', is another very important agroforestry tree species of this region. The distribution pattern of $T$. undulata in desert area of India is quite obvious because of its drought tolerant nature. High quality of timber, fuel wood and fodder place this species as most desirable throughout arid tracts. With the introduction of agroforestry models and changing scenario of agricultural practices in the arid and semi arid regions, newer pest and disease problems have been realised. Moreover, pressure of human and animal population is so high that the balance of demand and supply is thrown out of proportion. Very high livestock population causes acute shortage of fodder. There is a chronic deficiency of fodder to the tune of 16 million tonnes annually in the arid region. The gap between the demand and supply of fuel wood is of the order of $1.65 \mathrm{~m}$ tonnes per annum. The solution of all these problems appears to be a sound multi-tier production system of forestry management system with protection of natural resources from biotic interference including prevention from insect pests and mites. 


\section{Prosopis juliflora:-}

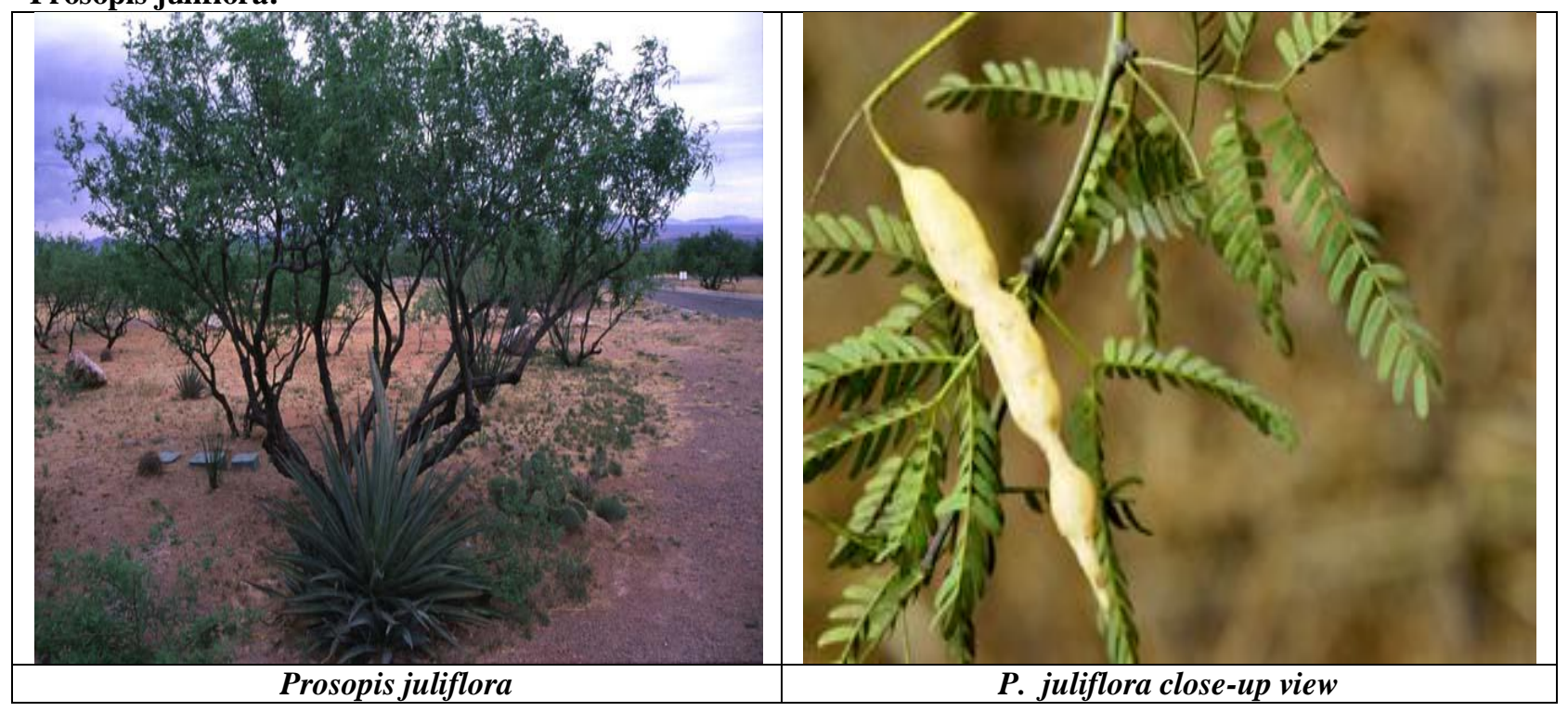

Prosopis juliflora is known as in Hindi -Vilayti babul or Vilayti khejra; Gujrati-ganda babool; Punjabi-Vilayti babool, Vilayti jhand, Vilayti kikar. Realising the slow growing nature of $P$. cineraria, another species of this genus, $P$. juliflora was introduced into the Indian sub-continent to Sind province (Pakistan) in 1877 from South America and later on it was introduced into many dry regions of India (Muthana and Arora, 1983). This species has since become naturalised in the arid and semi-arid parts of the country. With its wide adaptability to arid environments and its drought and disease tolerance, $P$. juliflora has virtually exceeded all indigenous species in covering the arid and semi arid tract. It forms thickets on marginal lands, sandy, rocky and gravely wastelands and alongside roads and railways and is now one of the major sources of fuelwood to the landless and poor populations. In Tamil Nadu, Haryana, Gujarat and Karnataka, farmers raise P. juliflora hedges along their field boundaries. Its presence all over the area has reduced the threat to important indigenous tree species like $P$. cineraria, Acacia nilotica and A. senegal, and today it is one of the most important species for desert reclamation (Saxena and Venketeshwarlu, 1991). In western Rajasthan P. juliflora is a major source of fodder, fuelwood, charcoal, timber and gums, and has established itself as a species of soil conservation and for aesthetic purposes. It also provides utility to wildlife in the arid tracts of Rajasthan and Kutch. Clusters of bushes or thickets provide hiding places for wildlife from hunters and natural enemies. Ripe fruits of this species have become the main source of nutritive food to wildlife. Ripe pods are consumed by livestock in large quantities in drought and especially in famine conditions. The pods also serve as the main protein source for milk cattle. Presently $70 \%$ or more of the fuelwood demand of people in the arid and semi-arid tract of Rajasthan, Gujarat and Haryana is met by this species. It has a high calorific value and is preferred over indigenous species. The plant produces gum from February to April which is used for sizing cloth and paper. Gum production is approximately $40 \mathrm{gm} / \mathrm{tree} / \mathrm{yr}$. Taken together, $P$. cineraria and $P$. juliflora is a very complementary and powerful pair of species in providing fuelwood, forage and increased fertility to the arid zones of India.

\section{Insect pest of Prosopis sp:-}

As many as 154 insect species (Table 1) belonging to 113 genera and 48 families under eight insect orders viz., Coleoptera, Hemiptera, Diptera, Hymenoptera, Isoptera, Lepidoptera, Orthoptera, Thysanoptera and one species under non-insect order i.e., Acarina have been recorded feeding on Prosopis cineraria (69 species) and P. juliflora (28 species ) and other Prosopis species (68 species) from all over the world. Out of these, 96 insect species belonging to eight orders have been recorded from Indian Sub continent. Of them, 33 insect species have so far been reported from arid and semi-arid tracts of distribution which include the States of Rajasthan, Haryana, Gujarat and Punjab. A part from insect fauna, only one species of non insect pest, Eriophyes prosopidis (Eriophyidae: Acarina) has also been recorded to cause severe damage by inducing leaf and inflorescence galls in $P$. cineraria in Rajasthan. Important insect pests are classified and grouped on the basis of the nature of injury caused by them. All the pests have been categorised as defoliators (D); sap-suckers (SS); living wood borers (LWB); dead wood borers (DWB); bark borers (BB); seed borers (SB); twig girdlers (TG); gall formers (GF); 
nursery pests $(\mathrm{N})$; and root feeders (RF). Majority of insects are polyphagous and only causally infest $P$. cineraria and $P$.juliflora but some are potential pests and occasionally cause epidemics in the plantations. The percentage of incidence (Mild- 1 to 10\%; Moderate- 11 to 40\%; Severe- 41\% and above) has been recorded by observing the attack of only 25 insect pest species which are kept under regular and periodical observations. Summarised the details of newly recorded fifteen species of insect pests categorised on the basis of their nature of damage whereas contains the world-wide information on the number of species under various pest groups and their potentialities on Prosopis spp.

\section{Defoliators:-}

30 Species of insects belonging to the orders Coleoptera, Lepidoptera and Orthoptera are associated with Prosopis species and cause mild to severe defoliation by feeding on the foliage during the different stages of their development.

\section{Coleoptera (Beetles and weevils):-}

The order is represented by 11 species from India and abroad to feed on foliage of Prosopis species. Of them, only three species frequently cause severe damage. Holotrichia consanguinea causes severe injury to the seedlings. Its larvae are causing large scale damage in the nursery stage and the adult beetles feed on the foliage in arid areas of India whereas four other species viz., Epicauta arizonica, Anoinala spp, Adoretus spp. and Schizonycha nyicollis has been reported to cause mild to moderate defoliation of Prosopis spp., from abroad. (Parihar, 1980, 1993; Parihar and Singh, 1998). Myllocerrus dorsatus has been recorded for the first time, infesting in nurseries and young plantations. The adults of $M$. dorsatus feed on the foliage of various dicotyledonous trees including Acacia sp., Albizia sp., Casuarina equisetifoila and Azadirachta indica (Beeson, 1941; Ahmed, 1992). Polyphagous nature of M. dorsatus has also described by Tewari (1992). Mild defoliation of M.dorsatus on Prosopis cineraria has been noticed during July to September at Jodhpur. Beetles and larvae of Clytra succinata feed on the tender leaves and buds. Larvae of a melolonthine beetle, Lachnosterna consanquina has been reported to cause a mild attack on foliage (Parihar and Singh, 1998). The adults of $H$. consanguinea, Rhinyptia laebiceps and R. meridionalis (Scarabaeidae) and of some other white grub species viz., Lachnosterna consanguinea, Adoretus sp., Schizonycha ruficollis, Anoimal sp. (Meloidae) have also been reported from other part of south east Asia to feed on the leaves during rainy seasons (Singh, 1998) but these species have not been encountered during the course of present investigations.

\section{Lepidoptera (Butterflies and moths):-}

12 species of Lepidoptera have been observed attacking young seedlings and plants of Prosopis species from all over the world. Of them, The larvae of Taragama (=Streblote) siva, are found to be the most notorious defoliator which feed on foliage irrespective of any age group of plant in arid areas of India. The severity of attack of $T$. siva can be judged by the presence of countless white cocoons which are present on the twigs, branches and even on the main trunk of Prosopis juliflora in case of epidemic areas. The pest population starts building up from the months of June and reaches to its peak during the month of August and September, when whole of the plantation exhibits a look of complete defoliation with the presence of abundant population of immature stages. Two species viz., Melipotis indomita and Amsacta moorie cause moderate defoliation whereas rest of them inflict mild attack on the foliage. The attack of $M$. indomita has also been reported by Uckert and Wright (1994) and Deloach and Cuda (1994) on P. flexuosa from North America. Mathur and Singh (1961) reported the attack of Casama vilis in the nursery stock of Prosopis spp., from north India. Kumar et al.,(1994) have reported that the larvae of Euchrysops sp and Pelopidas mathias defoliate P. cineraria in arid zone. Singh, (1998) reported that the larvae of Brachyphatnus sp, Teralopha euphemella and Melioptis bisinauta defoliate P. glandulosa, $P$. chilensis from North America whereas the larvae of Atlides halesus causes damage on P. glandulosa and from South Asia. Recently, a moderate attack of Noorda blitealis and Achaea janata has been noticed on both the species of Prosopis spp., in arid and semi-arid region in the month of July and August. Pest status of these two species has been recorded for the first time in India.

\section{Orthoptera (Locusts and grasshoppers):-}

The order is represented by six species which cause mild to moderate defoliation to Prosopis spp. Out of which, only one species Schistocerca gregaria is recorded to feed on the foliage and exhibits its potentiality as a pest at the time of swarming in arid areas. The nymphs and adults of S. gregaria feeds on the foliage during August to October at Jodhpur and cause moderate infestation to Prosopis seedlings in nurseries and young plantations. Poekilocerus pictus, commonly known as Aak grasshopper, is a primary pest of Aak ( Calotropis sp.) but its infestation has also been reported on Zizyphus mauritiana, (Parihar, 1987). The nymphs and adults were seen feeding on the foliage, 
making irregular holes on Prosopis cineraria (Kumar et al., 1994). Recently a large number of seedlings of $P$. cineraria and $P$. juliflora have been noticed to exposed with a severe attack of $P$. pictus in various nurseries. Holochlora indica, a polyphagous and general pest of forest nurseries, has been recorded to cause considerable damage in some of the forest nurseries having seedling of Prosopis spp., whereas nymph and adults of Lantana inflata are seen to cause specific and preferable damage to Prosopis cineraria in arid areas. Singh (1998) listed Dichroplus pratensis and Anacridium rubrispinum and causing infestation to Prosopis sp from North America and asia respectively.

\section{Sap-sucking insects:-}

Insects with sucking or rasping mouth parts may produces extensive chlorosis, but their feeding has little direct effect on yield and quality of crops. Scale insects, bugs (Hemiptera; 26 species) and Thrips (Thysanoptera; 2 species) are the main sap suckers on Prosopis spp. Adults and nymphs suck the cell sap of phyllodes and tender leaves and shoots as a result of which affected parts of young seedlings and plants are devitalized and exhibited stunted growth. Certain species are implicated in inducing physiological reactions ( Ananthakrishnan,1984). However, these insects are the most noteworthy for their role as vector of plant diseases (Coulson and Witter, 1984). 28 sap-sucking species belonging to only two orders viz., Hemiptera and Thysanoptera comprising twelve different families have so far been reported to cause injury to Prosopis sp form India and abroad.

\section{Hemiptera (Bugs):-}

There is a rich fauna of hemipterous bugs associated with Prosopis spp. The order is represented by 26 species belonging to 11 different families. All the 27 species are sap-sucking in nature. Browne (1968) has listed only six species. Of them, only two species viz., Oxyrachis tarandus and Drosicha stebbingi are frequently found in arid areas to cause mild to moderate damage to seedling and young plants. Severe damage caused by the nymphs and adults of Chlorochroa lingata resulted in abscission of the tender growing shoots of P. spicigera sp., in North America (Ueckert and Wright, 1974), whereas similar type of attack has also been noticed in $P$. cineraria in nursery stage at Jodhpur during the month of Febeuary and March caused by Neodartus sp. David and Subramaniam (1976) reported an Aleyrodid species, Acaudaleyrodes rachipora, to cause injury to Prosopis spp., from South India. The attack of $A$. rachipora has also been recorded on $P$. cineraria in arid and semi- arid areas with a severe intensity of infestation is in the nurseries. This species is highly polyphagous in nature and injures plant in a variety of ways. High populations, feeding on nutrient, affect the plants by physiological process which follows growth retardation and reduced vigour. Chlorotic spots appear at feeding sited on leaf surfaces. Vast amounts of honey dew produced by larvae leads to mould development on leaves and adversely affect photosynthesis (Sunderaraj and Murugesan, 1996). Parihar (1993), Kumar et al., (1994), Yousuf and Meeta (1998 a) have reported Oxyrachis tarandus, O. rufescens and Eurybrachys sp., infesting $P$. cineraria and $P$. juliflora from arid areas throughout the active monsoon. The eggs are laid on shoots in a V-shaped slit and injury often results in the stunting or ultimate death of the infested shoot. The scar made by $O$. tarandus is often used by other insects as a site of oviposition. The nymphs and adults feed gregariously on the sap of the tender shoots. The feeding insects excrete honeydew which is usually attended by several species of ants. Eurybrachys tomentosa is the new pest record infesting $P$. cineraria in arid and semi-arid areas. Eggs are laid in clusters, 30-40 eggs per egg mass, on the surface of the leaf or on the bark. One female may lay about 6 egg masses containing about 200 eggs which hatch in 2-3 weeks. Newly hatched nymphs are gregarious in nature. The frequent and repeated feeding of this leafhopper checks the growth of new shoots. As a result of which the leaves are shed and young shoot died. Nezara viridula a polyphagous sap-sucking bug, has been noticed to infest seedlings of $P$. juliflora and $P$. cineraria in the experimental fields. The attack of this species has been recorded for the first time in arid areas.

Parihar and Singh (1998) and Singh (1998) reported about 20 insect species as sap suckers infesting Prosopis spp., from North America and South Asia. Of them, about 14 species viz. Declera levan, Hoemoecerus prominulus, Omanacoris versicolor, Campyloma sp, Macropsis sp, Mozena obtusa, Oxycarens hylinipennis, Microphylidea prosopidis, Neurocolpus arizonae, Orthotylus vigilax, Phymatoprallus prosopidis, Phytecoris lenis of Prosopis species are mentioned as the potential pests. Diceroproproctus apache is the only insect feeding on the root sap, (Singh,1998).

\section{Thysanoptera (Thrips):-}

Thrips are very small microscopic insects, measuring 0.5-3 mm., in length, belonging to the order thysanoptera. There are about 5000 species reported from all over the world. Some of which are known to cause serious economic damage and the phytophagous species are confined to flowers. The nymphs and adults of Frankliniella schutzei 
were reported to infest P. cineraria and P. juliflora in arid areas (Parihar, 1993; Murugesan and Shivesh kumar, 1996). The damage is evident with the drying and wrinkling of infloresence in case of heavy infestations. All parts of the flowers are infested and several adults and nymphs were found inside each flower. A mild attack of $F$. dampfi has also been recorded on the P. juliflora during the flowering season in the month of February to March and August and September. This species is a new pest record on $P$. juliflora from arid areas.

\section{Dead wood borers:-}

All the dead wood boring insects of Prosopis spp., belong to the Order Coleoptera. 25 species of wood borers belonging to round headed borers (Cerambicydae; 2 species); flatheaded borers (Buprestidae; 7 species) and powder post beetles (Bostrichidae,Dermestidae, Lyctidae; 16 species) cause mild to severe damage to the felled or stocked timber of Prosopis spp. A few species comprising Sinoxylon anale, Crysobotheris beesoni (Beeson, 1941); Lyctus africanus, S. capillatum (Mathur and Singh, 1961), Chrysobotheris laterallis, C. octicola and Stromatium barbatum (Singh, 1998); C. purvipuncata and Phradonoma nobile (Parihar and Singh, 1998) have been reported to cause severe injuries to freshly felled stocked timber of Prosopis species in arid areas. Other important species viz., Apate monachus, Sinoxylon crassum dekkanese, Trogoxylon spinifrons, T. auriculatum, Lyctoxylon japonum, Xylonites spp, Crysobotheris andamana (Mathur and Singh,1961; Browne, 1968); Amphicerus sp., and Dendrobiella sp., (Singh,1998) have been reported from Asia and North America. Acmeodera aurifera (Buprestidae) and Acanthophorus serraticornis (Cerambicydae) have recently been noticed to cause severe damage to dead stocked logs of Prosopis cineraria in Rajasthan. Acmeodera aurifera and Acanthophorus serraticornis are among the newly recorded dead wood borers from arid and semi arid areas.

\section{Insect pests of seed:-}

The insect pests causing damage to the seed and pods of Prosopis spp., are represented by 31 insect species belonging to seven families Bruchidae, Curculionidae, Blastodacnidae, Cochylidae, Notodontidae, Olethreutidae and Pyralidae under two insect orders (Coleoptera and Lepidoptera). Bruchus uberatus is a common seed weevil, larvae of which are destructive to the seed of several tree species (Browne, 1968). Larvae of B.uberatus feed on the interior of the seed, hollowing it out and passing onto the next seed in a pod of P. juliflora (Parihar and Singh, 1998). Adult females attach their eggs singly to the pods. Larvae, after hatching, start burrowing directly through the pod wall and the seed coat to feed on the cotyledons. Larval development is completed within a single kernel. When mature, larvae may partially or completely emerge from the pod, leaving a characteristic round hole. Caryedon serratus has been reported to be the most noxious pest of leguminous tree seed in India (Beeson, 1941; Satyavir, 1996; Singh, 1998). Seed of $P$. cineraria are generally attacked by this species at Jodhpur. The eggs are laid on the pods or on the seeds and the contents of the latter are eaten by the growing larvae, which eventually pupate in ovoid cocoons of tough silk. Jhonson and Siemans (1997) reported Algarobius prosopis infesting seeds of Prosopis spp., from North America. Singh (1998) has listed 27 species from all over the world. Of them, only Caryedon gonagra and Bruchus bilineatophygus have been encountered to cause damage to the seed stock in arid areas of India (Singh, 1998). Bruchidus albizzae has been recorded for the first time to infest stored seed of Prosopis cineraria at Jodhpur.

\section{Insect pests of nurseries:-}

Major insect pests causing damage in the Prosopis spp., seedlings in the nurseries and newly raised plantations are represented by 4 species of Orthoptera, one species of Lepidoptera, one species of Coleoptera and three species of Isoptera. Potential nursery pests include two species of family Gryllidae viz., Gryllus domesticus and Brachytrypes portentosus. G. domesticus is commonly known as 'house cricket'. A mild to moderate infestation of this pest has been recorded on the young seedlings. Nymphs and adults feed on the tender leaves and also devour sown seed in the polybags. This species has been reported by Verma and Vir (1995) with its identity as G. domestica whereas Parihar and Singh (1998) have named this species as Acheta domesticus. Another species Gryllus gryllus has also been reported by Verma and Vir (1995) but during the present studies no such species could be noticed to cause damage to the nursery stock. The grubs of $H$. consanguinea were found, damaging 3-4 week old Prosopis spp., seedlings in the sandy tract of Jodhpur. The grubs completely ate away the roots of the seedlings in patches, resulting the retransplantation of seedlings. Brachytrypes portentosus is blackish-brown cricket and reported as a general pest in forest nurseries and young plantations. Severe damage of this species was observed in the seedlings of $P$. cineraria in the nursery stage for the first time in arid areas. The adults make deep tunnels in the soil or polybags and lay their eggs in them. Nymphs, after hatching, start feeding on the rootlets. Nymphs and adults also prefer to feed on the leaves and growing tips. Sen-Sarma (1983) and Sen- Sarama and Thakur (1986) reported Agrotis ipsilon damaging Prosopis spp., seedling in nurseries from Rajasthan. 


\section{Isoptera (Termites):-}

Three species of termites were observed to infest Prosopis spp. They cause a considerable damage to the dead wood as well as living trees. Odontotermes obesus (Syn: Cyclotermes obesus), and Microtermes obesi (Termitidae) subterranean and mound building termites, are recorded to be the most injurious in nurseries and plantations of Prosopis spp (Parihar,1993; Kumar et al., 1994). The infestation caused by Microtermes mycophagous, has also been reported by Parihar and Singh (1998) in the young plantations of Prosopis spp. They forage from their nest by means of runways to dead wood or to the roots and bark of living plants.

\section{Gall formers:-}

When feeding on plant tissues, many insects and mites inject or secrete a chemical substance into the plant that causes the plant to grow abnormally and produce a gall. Stimulus for gall formation is usually provided by the feeding stage of the insect, but in some insects the ovipositing female provides the stimulus when she lays eggs on the plant. Galls may be found on leaves, buds, stems, or roots. Plant galls are caused by insects, mites, nematodes, bacteria, fungi, and viruses, but most galls are produced by insects and mites. Seven insect species belonging to six families under three insect orders Hymenoptera, Diptera, Lepidoptera and one non insect, under order Acarina, have been reported to induce gall formation in P. cineraria in arid and semi arid regions. Eurytoma sp.,(Eurytomidae) is reported to cause gall formation in P. cineraria (Sacchan and Pal, 1972). Parihar (1993) has stated that this species a parasite of Pediobopsis sp., which itself has been observed to induce gall in $P$. cineraria. In the present investigation, it has been noticed that the stem gall in P. cineraria are caused by the attack of Eurytoma settitibia which is a new pest record from Rajasthan. E. settitibia Gahan forms woody galls on branches during young to mature stage. The production of galls on the trees hampere the growth of the new branches. Parihar (1993) reported Contarinia prosopidis Mani(=Lobopteromyia prosopidis) forming monoliform globose galls on rachis of $P$. cineraria. Almost all the stages of the plant development are infested by this species. One or more adult cecidomyiids emerge out from a single gall, leaving exit hole on the gall periphery. The trees ranging between two to three years old were found more susceptible for infection. Parihar (1993) has reported four species of moths (Microlepidoptera) viz., Assura albicostalis, Anarsia triaenota, Eucosma lioplintha and Ascalenia spp., are causing inflorecence gall on $P$. cineraria but in present investigation, it has been observed that the role of these microlepidopteran in the gall formation is not at all involved. They remain in the gall as inquilines untill the completion and maturity of their life stages and emerged from the exit holes, excavated by a mite, Eriophyes prosopidis which is primarily responsible to form leaf and inflorecence galls on $P$. cineraria. The inflorecence galls are smooth masses of oval, pyriform, globose, ocassionally lobed. The galls are green initially, but turn raddish brown on their maturity. The leaf galls are present on the both the surfaces of the leaf. The gall density increased from June to July. The mite breed reducing enormous galls on the leaflets. Galls are scattered irregularly over the lamina or some time restricted to the angles between veins. (Mani,1964 and Parihar, 1993).

\section{Management of insect pests of Prosopis sp:- Biological control:-}

Natural enemy complex recorded on the insect pests of Prosopis cineraria and P.juliflora during the course of these investigations, play a major role in controlling the outbreaks of insect pests of these economically important tree species in arid and semi-arid regions. The interrelationships among host insects and their natural enemies are presented in .Nineteen species of parasites, thirteen species of predators and three species of entomopathogens were found associated with the potential insect pests of Prosopis spp. Klapwik et. al. 2016 described about the forest management and natural bio-control of insect pests.

\section{Parasites:-}

Eupelmid sp., (Eupelmidae: Chalcidae), an effective egg parasitoid, was found to parasitise the eggs of Halys dentatus, Eurybrachus tomentosa and Homoecerus prominulus which are recorded to cause mild to moderate damage in the nursery and young plantations of Prosopis spp. Whereas an species of Eupelmus (Eulophidae: Chalcidae) plays an important role in the regulation of gall forming insects Contarinia prosopidis and Eurytoma settitibia population by feeding on their larval instars. The adults of Tetrastichus spirabilis Waterest (Eulophidae: Hymenoptera) have also been observed to parasitise the larvae of rachis gall midge, C. prosopidis. Apanteles sp., (Braconidae) parasitises the eggs of four species of important pests viz., Achaea janata, Noorda blitealis, Bruchidus uberatus and Caryedon serratus. Two species of trichogrammatids, Trichogrmma roi and Brachygrammatella aligarhensis were found to be associated with A. janata and Oxyrachis tarandus. Ufens brevifuniculata has been collected from the eggs of $O$. tarandus. The white fly, Acaudaleurodes rachipora was noticed to be attacked by three species of parasites and six species of spiders namely Encarsia acaudaleyrodis, Encarsia sp., and Eretmocerus 
rajasthanicus and Neoscona theis, Theridon sp, Peucetia sp, Cyrtarachne sp, Parawixia sp and Cheiracanthium sp., respectively. Field population of white grubs, Holotrichia consanguinea is frequently observed to be parasitised by Scolia aureipennis, Campsomeria colloris and Tiphia sp., (Hymenoptera). The larvae of a drywood borer, Acmeodera aurifera were found parasitised by four species of Hymenopterous parasites viz., Teretriosoma stebbingii,Bracon sp., Chaoilta sp., and Hacabolodes radiali. Carcellia buitenzorgiensis Bar. (Diptera) has been recorded as a potential endoparasite of the larvae of $T$. siva.

\section{Predators:-}

The green lace-wing, Chrysopa scelestes (Chrysopidae) was found to be one of the most efficient predators of flower thrips, Frankiniella schultzei and F.dampfi. Since $C$. scelestes adults are not predatory, the feeding behaviour of the larvae involves a series of stimulus response events as evident in all the predatory insects like anthocorids and coccinellids. C. scelestes detect the presence of the prey only by the contact of mandibles. After immobilising the prey by injecting the saliva, the larvae sucked out fluid contents (Suresh kumar, 1985).The adults and nymphs of Canthocona blanchia and C. furcellata (Pentatomidae) were observed to predate on the immature stages of Oxyrachis tarandus and Eurybrachis tomentosa. The adult bug approaches the host, extend its sucking pump and insert it into the body of host at a place generally near the tip of the abdomen. The prey wriggles for few minutes after the predator inserts the sucking pump and then become stupified afterwards. The body fluid is completely sucked by the bug. An other species of a pentatomid bug, Clavata jugatoria follows the larva of Taragama siva and attacks it from behind. Once the enemy is sufficently near, the proboscis is introduced in a outstreched position. In final stage larval instar, the piercing of the proboscis is not easily effected as the former turns and attacks the enemy. Adults of one more species, Halymorpha picus Fabr. (Pentatomidae) were found feeding on the larvae of Achaea janata. Only the adults of this species attack the early instars larvae and eggs. Acanthaspis flavipes Walk., is one of the general reduviid predator of white flies, aphids and thrips. For catching its prey the predator bug jumps forward and victim is grasped by the front legs and pierced with stylets of the rostrum at the same instant. Within a short period of half a minute or so, the prey is paralysed and then feeding may proceed on the body of the assailant. Feeding is continued untill liquid of the host body is exhausted after which the carcass is thrown away. Creoboter urbana Fabr., is a small brownish-green mantid with a round yellow "eye spot" ringed and centered with black on each tegmen. The adults and nymphs of this general predator attack early stages of lepidopterous pests viz., Taragama siva and Achaea janata. Beeson (1941) also reported its feeding on caterpillars and moths of various forest pests. Diephobe infuscata Saurs., is another species of mantid which feeds on a number of minute insect pests of Prosopis spp. Ahmed (1982) has also reported this species to attack larvae of Calopepla leayena.

\section{Vertebrate predators:-}

In addition, nine species of birds are generally encountered to be predacious on several insect pests of $P$. cineraria and P. juliflora. Of them, Ploceus philippinus philippinus Linn., (Indian Baya),Nectarinia asiatica asiatica Lath (Indian purple sunbird),Turdoides striatus striatus Dumont (Jungle Babbler), Copsychus saularis saularis Linn (Red vented Bulbul), Acridotheres tristis tristis Linn (India Myna), Dicrurus paradiseus paradius Linn (Racket-tailed Drango), Upupa epops epops Linn (Hoopoe), Merops orientalis Lath (Common green Bee-hunter), Nyctyornis athertoni athertoni Jord (Blue bearded Bee-hunter) are the most potential general bird predators of several species of insects of Prosopis spp., in arid and semi arid areas.

\section{Entomopathogens:-}

Two species of entompathogenic fungi namely, Beauveria bassiana and Aspergillus parasiticus and one species of insect pathogenic virus, the nuclear polyhedrosis virus were observed to infect three species of insect pests of Prosopis spp., in arid and semi arid areas. The white grubs of Holotrichia consanguinea were found severly infected by $B$. bassiana and $A$. parasiticus in the polybags having seedlings of $P$. cineraria. Though, there are numerous reports on the natural epizootics of fungi that reduced the insect outbreaks (Otvos and Moody, 1978; ESC, 1986) but very few reports claimed such epizootics have been induced artificially (Brucher, 1964). Dresner (1949), on the other hand, concluded that entomopathogenic fungi could provide inexpensive and long lasting control of insect pests. Since $B$. bassiana and A. parasiticus infect the white grubs on contact by penetrating through the integument, they have one major advantage over other pathogens as they are not restricted in the stage of development that they can attack. Hence, further research is needed on this aspect in order to work out an effective strategy of biological control of white grubs attacking $P$. cineraria. Larvae of the lasiocampid defoliator, Taragama siva were seen to be highly susceptible to the infection caused by a nuclear polyhedrosis virus throughout arid areas. Role of this virus in controlling the T. siva populations has been discussed by Ahmed and Shivesh Kumar (1998) and Ahmed et al., (1998). NPV- infection on another noctuid defoliator, A. janata has also been reported by Ahmed and Murugesan 
(1995). Judging from the results that have been published by several earlier workers (Cunnigham, 1985; Ahmed, 1994, 1996; Ahmed and Leather, 1994), it is now possible to control these injurious pests of Prosopis spp., by the application of viral suspension.

\section{Bioefficacy of potential parasites:-}

Larval parasite Eupelmus sp. (Eulophidae: Hymenoptera):-

A large number of maggots of Eupelmus sp., were collected alongwith the larvae of Contarinia prosopidis and Eurytoma setttitibia from the mature rachis and stem galls of $P$. cineraria. The adults of Eupelmus sp., were seen emerging in field in the morning hours and their activity was noticed till dusk. A few mating couples were also observed on the leaves and branches. The copulation takes place soon after the emergence of adult parasites. The male closely follows the virgin female abdomen with its antennae which vibrate very rapidly. While following the female, the male moves his body side wise in a rhythmic way. The male parasite then mounts upon the female body, clasping the abdomen by means of first pairs of legs. The act of copulation lasts 2-4 seconds. A mated female does not permit a second mating. A male can, however, copulate with many females. Mated female hovers over the freshly developing rachis or stem galls containing newly hatched host larvae, alights on one of them and oviposits by inserting its ovipositor inside the gall. The ovipositing female can easily detect a suitable gall for oviposition.

\section{Larval parasite, Tetrastichus spirabilis Waterest (Eulophidae: Hymenoptera):-}

While searching for immature stages of Eupelmus species some dull coloured globular larvae were found inside many of the galls. They also attack the $C$. prosopidis larvae externally. On the emergence of adults the identity of this parasite is confirmed as to belong to the genus Tetrastichus and species spirabilis. It is a small solitary ectoparsite of early instars larvae of $C$. prospsoidis and E. settitibia. The female parasite attack the newly hatched larvae which turn black on the next day after parasitization. It was observed that the male parsites of this species, on emergence, wait on the surface of gall from which they emerged. As soon as a female emerges, a concerted rush is made at her, and the sucessful male mates. The act of mating takes a few seconds. The female climbs on to the tender rachis and twigs and pushes the ovipositor down through the soft plant tissues. All the eggs in one sitting were not necessarily deposited by the female. It was also noticed in a series of experiments that only those ovipositing sites were chosen by the parasite which are already selected by the galling insects for their oviposition. An average measurement of body length of male and female individuals were recorded to be $0.87 \pm 0.02 \mathrm{~mm}$., and $1.21 \pm 0.04 \mathrm{~mm}$., respectively. Both the species of parasites were encountered to live and attack together to their host larvae. The adults of both these species are swift fliers and noticed in the field during warm sunny days. After emergence, the adult parasites escape from the galls through the same opening excavated by the gall insects.

\section{Silvicultural control:-}

Data obtained on production of foliage per meter cube also reaveled significany difference in foliage production under lopped $(202.5 \mathrm{mg}$ ) trees and unlopped $(184.8 \mathrm{mg}$ ) trees during February. Difference in green weights of the foliage in both the cases may, probably, be due to the two important factors viz., (i) leaf gall infestation and (ii) aging of leaves in unlopped trees in winter months. Though, there is no significant difference in fodder production in the trees which were lopped during different seasons of the year but in case of unlopped trees, a marked difference in percentage production of leaf foliage was recorded (Ganguli et al., 1964). Sharma and Gupta (1981) also reported similar observations on lopped and unlopped trees of $P$. cineraria. Thus, a comparision of these studies leads to conclude that a $P$. cineraria tree yields much more in forage and fruit production under lopped conditions. Studies suggest that the lopping pattern allows the tree to attain a well developed crown and a balanced canopy and this may be due to the fact that lopped trees remained less infested by the gall mite attack. 
Azardirachta indica:-

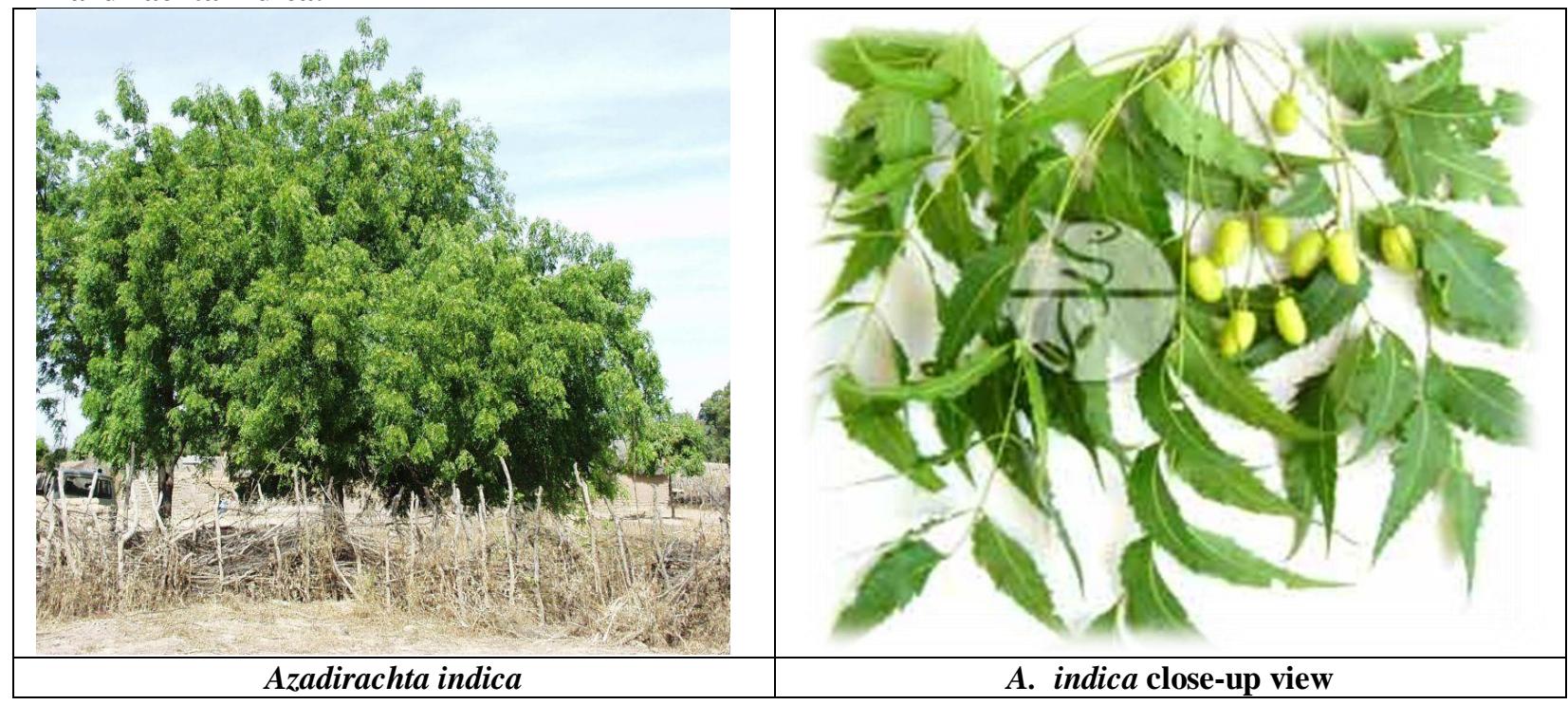

Insect and non-insect pests of neem and their management:-

For the sake of convenience the pest spectrum of neem has been described under three heads viz., Acarina (mites); Gastropodes (molluscs); and Insecta (insects):

\section{Acarina:-}

Five species of mites are recorded viz., Eutetranychus orientalus (Klein), E. maximae Nassar and Ghai, E. phaseoli Nassar and Ghai, E. bilobatus Nassar and Ghai and Red spider mite, Tetranychus spp. (Acarina : Tetranychidae) to cause considerable injuries to nursery stocks of neem. All stages suck sap from the leaves resulting in white spots due to loss in green matter, ultimately the leaves turn yellow and fall. The severe attack of mite cause growth retardation in young seedlings.

\section{Gastropoda (mollusca):-}

Two species of gastropod molluscs are reported to cause damage to neem seedlings in different forest nurseries of arid and semi arid regions.It includes two species of snail and one species of slug. Common garden slug, Laevicaculis alte (Ferussac) (Gastropoda) is a soft bodied animal, dorsal surface blackish brown, ventral surface creamish white in colour. Eggs are laid in soil in a loose mass of about 60 in number.It causes severe damage to neem seedlings by voraciously feedling on the tender stem and the foliage of neem seedling. The body of common Indian snail, Macrochlamys indica Godwin-Austin (Gastropoda) is spirally coiled and enclosed in a protective calcareous shell which is perforated, pale brown with smooth and polished surface, with five and half whorls and a low spire. The snails are abundant during the monsoon causing damage (10-16\%) to neem seedlings in forest nurseries and young plantations in areas around Jodhpur. The snails rasp the epidermis and eat the mesophyll tissue of leaves. They also feed on green portion of tender stem removing the bark completely.

Insecta (insects): Orthoptera:-

Grasshopper, Orthacris simulans (Orthoptera : Acrididae): It is a greenish wingless grasshopper and both nymphs and adults feeds on mature leaves.

\section{Isoptera (Termites):-}

Seven species of root feeders are reported to cause damage to neem in India (Tiwari, 1992). Recently four species of root feeders are reported from arid and semi-arid regions. Of them, one species of white grub Holotricha consanguinea viz., and three species of termites Odontotermes obesus (Rambur), O. redemanni (Wasmann) and O. gurdaspurensis Holmgren (Termitidae). The are among the common insect pests in arid and semi arid regions. Termite workers feed on the roots and stem portions irrespective of age and ecological parameters of neem plants. The damage occurs by hollowing out or by partly removing the bark of the roots and stem. Severely infested young plants may fell down and killed. 


\section{Thysanoptera (Thripes):-}

Out of five species of thripes, recorded from India (Tiwari 1992, Ahmed 1992), two species viz., green house thrips, Heliothrips haemorrhoidalis (Bouche) and Taeniothrips longistylus, Karny (Thripidae) have been reported from Rajasthan. Both adults and nymphs suck the sap of the foliage and shoots. Lacerating on leaves and puncturing of tissues by several individuals result in loss of green matter. Infested leaves become blotched and brown. Heavy infestation distorts leaves making them crinkled and mottled. Their damage in neem is of moderate intensity. All thripes species are the minor pests of seedlings.

\section{Hemiptera (Bugs):-}

Out of 23 sap sucking insect species as listed by Browne (1968); Schmutterer(1990); Pillai and Gopi (1990); Ahmed (1992); and Tiwari (1992)and reported from India on neem ten species are recorded to suck the sap of neem from arid and semi- arid regions. They cause considerable damage in nursery, young plantations and grown up trees. Both the nymphs and adults suck the sap from the foliage and growing shoots causing "die back". The most important among them are Tea mosquito bug, Helopeltis antonii Signoret ( Miridae), The oriental yellow scale, Aonidiella orientalis Newstead (Diaspididae), neem scale, Pulvinaria maxima, P. azadirachtae Green, Indian wax scale, Ceroplastes ceriferus Anderson, Wax scale, Ceroplastes pseudoceriferus Green, The shield scale, Lecanium sp. (Coccidae) and Pseudococcus sp. (Psedococcidae). During recent survey made in and around Jodhpur several egg masses of Eurybrachus tomentosa and one species of white fly Dialeurodes almatus were observed on tender leaves of neem at seedling stage. A pseudococcid Pseudococcus spp. was also recorded to cause severe damage in neem seedlings. An other hemipterous bug Helopeltis antonii Signoret (Miridae) poses heavy damage to young neem plantations. Both adults and immature stages of reddish brown bug sucks the sap from the tender shoots and leaves and inject a phytotoxin into the plant system. The injury made by the suctorial mouth parts of the pest cause the tender shoot to exude a gummy substances which on exposure to air gets hardened. In severely infested plants, the entire leaf dries up and the whole plant present a scorched appearance.

\section{Lepidoptera (Butterflies and Moths):-}

15 species of insect pests have been reported to cause injuries to neem from India. Of them seven species viz., neem shoot borer, Laspeyresia koenigana Fab. (Eucosmidae), castor semilooper, Achaea janata Linn. (Noctuidae) Semilopper, Boarmia variegata Moore (Geometridae) Looper moth, Cleora cornaria Guenee (Geometridae), Eurema spp. (Pieridae) Thosea bipartita, (Limacodidae), Leaf mine, Odites atmopha Meyrick (Xyloryctidae) have been encountered to inflict damage to neem in arid and semi arid areas. The neem shoot borer, Laspeyresia koenigana is the only one shoot borer of neem known from arid and semi-arid regions. The moth lays eggs on the tender shoots. The young larva, on hatching bores into the shoot and continue this habit throughout the process of its development. The later instars mine and feed in rolled leaves or in between the superimposed leaves, spun with silk. Many young larvae die due to the heavy quantity of gum exudation.

\section{Coleoptera (Beetles and weevils):-}

Out of 16 coleopterus pest species reported from India, six species of insects pests are recorded to be the most destructive pests on neem in arid areas. The ash weevil, Myllocerus dorsatus Fab. and Almond weevil, Myllocerus laetivirens Marsh. Cryptocephala aequalis spp. (Curculionidae) Ahmed (1992), and White grub, Holotrichia consanguinea (Blanchard) (Scarabaeidae). Recently two species of curculionidae found attacking fruits and inflorescence of neem in arid areas.(Ahmed and Goldy, 1998)

\section{Management of insect pests of neem:-}

Pest management is an essential part of tree planting programmes, including those in which neem is a component. The approach has to be integrated to make the afforestation programmes successful.

\section{Silvicultural control:-}

For better management, ideal silvicultural practices should be adopted. Selection of site, preparation of beds, soil preparation, protection against sun, rain and insects are the important aspects to be considered. It is being observed that neem is becoming susceptible to some of the insects such as tea mosquito, $H$. antonii the oriental yellow scale, $A$. orientalis and Myllocerus spp. which were primarily recorded as the pests of fruit trees but now they are causing wide scale damage to neem trees in India particularly in arid and semi-arid tracts of their distribution. It seems that these insects have selected neem as an alternative host in spite of their primary existence as being on the horticultural crops. Hence, raising of neem seedlings should be avoided near preferred horticulture crops by there pests. Prunning and removal of infested parts of plant along with the insect colonies may check the further attack. Recently, studies for the 
selection of best germplasm of neem to for insect resistance are being made by provenance trials at Arid Forest Research Institute, Jodhpur. Improving the genetic base of the neem tree through tissue culture technique may proved to be the best in increasing the resistance of future neem planting stocks to pest damages.

\section{Chemical Control:-}

There is a bewildering array of insecticides available in the market but their optimum dosages required to control epidemics of potential insect pests like L. koenigana, H. antonii, M. laetivirens, M. dorsatus and the long term effect of insecticidal spray on non target biota such as parasites, predators and pathogens, occuring naturally in the man-made plantations, are not known. Therefore, there is an urgent need to screen the available insecticides for their efficacy against pests. Occasional insecticidal spray becomes very essential specially at the seedling stage and in young plantations, because if not timely controlled the infestation may result in heavy economic losses. Some of the time tested chemical control measures recommended included : spray of a systemic insecticide, like monocrotophos $(0.02 \%)$ or dimethoate $(0.02 \%)$ to control the sap sucking insects such as $\boldsymbol{A}$. orientalis, $\boldsymbol{P}$. maxima and other coccids and scale insects whereas foliage feeding insects viz., B. variegata, Eurema sp. and Myllocerus spp. can be controlled by foliar spray by a of contact insecticide such as endosulfan $(0.02 \%)$ or malathion $(0.02 \%)$ infestation of root feeders like white grubs and termites can be controlled by spraying $0.05 \%$ endosulfan. Before raising seedling the soil should be treated with 10\% BHC dust@ 300gm/cubic meter of soil. Planting pit of 30x 30x 30cm should be treated with 50gm of BHC dust. or soil drenching with $0.02 \%$ chlorpyriphos before tree plantation checks the soil insects. The treatment has to be repeated as and when infestation is noticed. The young caterpillar of shoot borer Laspeyresia koenigana can be effectively controlled by spraying monocrotophos $(0.02 \%)$ in water or by dimethoate $(0.02 \%)$ in combination with blitox $(0.05 \%)$ and Vipul @ 2ml/lit. The mite infestation can be managed by controlled by spraying monocrotophos $(0.02 \%)$, whereas the molluscs can be controlled mechanically by hand picking method or by dropping them in a container having salt solution.

\section{Biological control:-}

Though application of chemical pesticides is one of the effective methods of pest control in forest nurseries and plantations but the insect pests are developing resistant towards insecticides and with the increasing environmental pollution it is now agreed that insecticidal application should be replaced by pest management strategies integrating silvicultural, biological, chemical and other methods to reduce the pest population below economic threshold levels. Use of biocontrol agents viz., entomophagous insects and entomopathogens is safe in a forest ecosystem. Practically very little is known regarding natural enemy complex of neem pest fauna. The field population of $\boldsymbol{A}$. janata was reported severely infected with a nuclear polyhedrosis viruses (Ahmed et. al.1989). The use of NPV Suspension has been proved to be most effective in comparison with that of chemical pesticides white grubs $\boldsymbol{H}$. consanguinea can be controlled with a standard preparation of Bacillus popilliae (Shinde and Sharma, 1971;) . A fungus Aspergillus parasiticus have been reported as naturally occuring on white grubs (Patel et al. 1977). Microbial pest control agents should be viewed as a biological resource for developing environmentally rational insecticides (Ahmed 1994) . A few insect pathogens including baculoviruses fungi, protozoa and bacteria are already in use in pest management (Ahmed and Leather, 1994) . Basic information on various pathogens, their host range and efficacy as a control agent under both laboratory and field conditions is to be worked out on neem in arid and semi arid regions.

Tecomella undulata:-

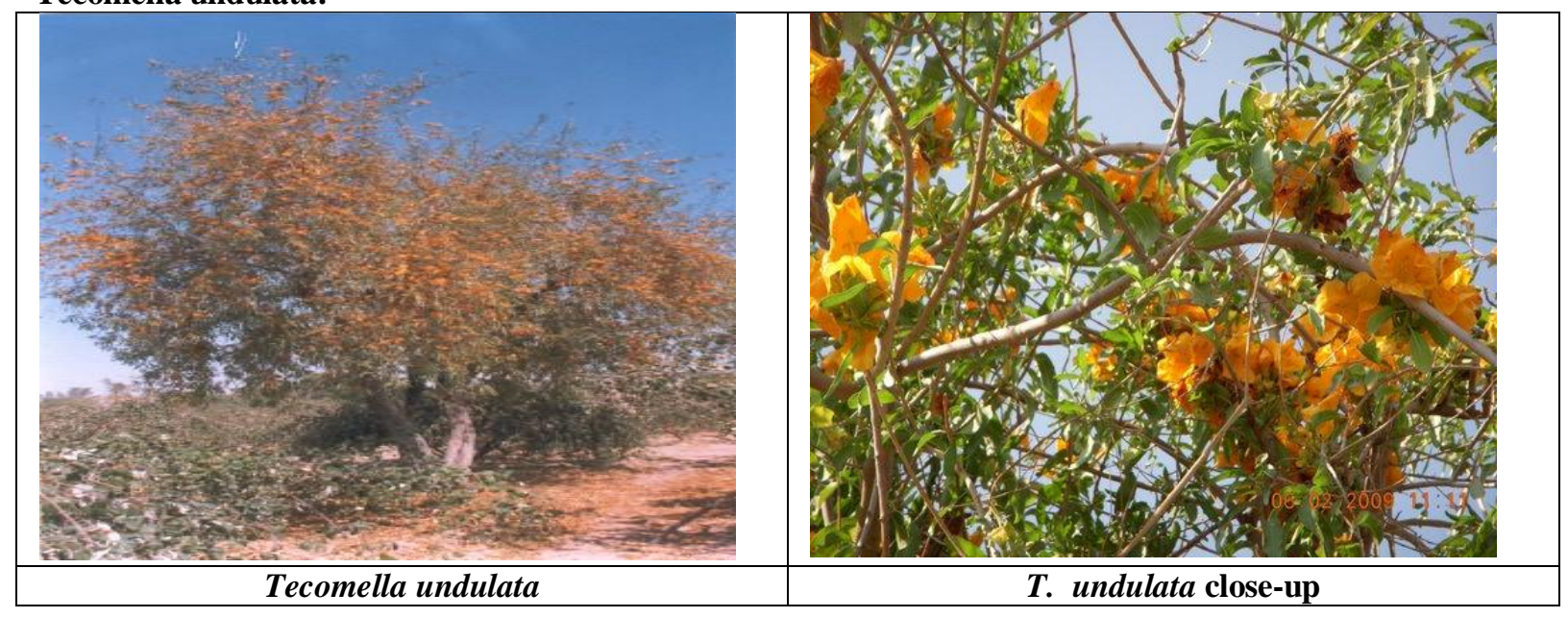




\section{Insect pest spectrum of rohida, Tecomella undulata:-}

About 64 insect species including 24 new pest records, belonging to 32 families under 6 insect orders, viz., Coleoptera, Hemiptera, Isoptera, Lepidoptera, Orthoptera, and Thysanoptera have been recorded feeding on $T$. undulata. Important insect pests are grouped as defoliators, sap-sucking insects, stem and root borers, dry wood borers, seed pests, leaf miners, nursery pests and termites . Majority of the insects are polyphagous and only casually infest $T$. undualta but some are potential pests and occasionally cause epidemics in the young plantations. The percentage of incidence (mild-1 to $10 \%$; moderate- 11 to $40 \%$; severe- $41 \%$ and above) has been recorded by observing the attack of the particular insect species on 100 seedlings, kept in three replicates in Arid Forest Research Institute Model- Nursery during these investigations.

\section{Defoliators:-}

27 species belonging to the orders Coleoptera, Lepidoptera and Orthoptera are associated with T. undulata and cause mild to severe defoliation by feeding on the foliage during the different stages of its development.

\section{Coleoptera (Beetles and weevils):-}

The order is represented by 23 species. Of them, only nine species are the important defoliators. Seven species of curculionid weevils are recorded to cause considerable damage by feeding on foliage. Larvae of Patialus tecomella skeletonize the leaves of the $T$. undulata whereas adults cut the margins in an irregular pattern and feed on the green matter but complete leaf is never be eaten by the weevils. About 80 percent seedlings are found to be damaged by this pest in the nursery stage. Five species of the genus Myllocerus cause considerable damage in the nurseries and young plantations. The adults of M.dorsatus feed on the foliage of various dicotyledonous trees, including Acacia sp., Albizia sp. and Casuarina equisetifoila and Azadirachta indica (Beeson 1941,and Ahmed,1992). Mild defoliation of M.dorsatus on T. undulata has been noticed during July to September at Jodhpur.M.discolor is a short snouted weevil with black and pale markings on the dorsal regions. Adult weevils are active throughout the year. Verma and Vir,(1995) also recorded this species damaging T. undulata.M.laetivirens feed on a variety of host plants (Beeson, 1941; Mathur and Singh, 1958 Verma and vir,1995; Kumar et.at.,1997). The adults were seen causing mild defoliation in the nursery-raised seedlings. M.maculosus and M.dalbergiae feed on the foliage of many dicotyledonous trees including T.undulata (Beeson, 1941;Verma and Vir, 1995). Severe damage of these species has been reported on the young seedlings for the first time in arid areas. Beetles and larvae of Amblyrhinus posicollis feed on the tender leaves and buds.Larvae of Holotrichia consanguinea are the severe pests of the young seedling causing large scale damage in the nursery stage whereas adult beetles feed on the foliage. Larvae of Melolonthine beetle, Autoserica nathani have been noted to cause a mild attack on the foliage.

\section{Lepidoptera (Butterflies and moths):-}

13 species of Lepidoptera have been observed attacking young seedlings and plants of T.undulata. Of them, 10 species are causing mild to severe defoliation. Amsacta moorie is commonly known as 'red hairy caterpillar'. The larvae of which are the voracious feeders on foliage particularly in the nursery stage. The larvae of'greasy cutworm," Agrotis ipsilon feed by night, cutting young seedling off, at ground level or removing bud and leaves whereas A.spinifera is widely distributed throughout arid and semi-arid areas of Rajasthan. Larvae of which are the nocturnal in nature and feed by cutting the seedlings from ground level. Although the attack of Mythimna separata has been recorded by Verma and Vir (1995) on T. undulata but this species was not encountered during the course of present investigations. The larvae of caster semi-looper, Achaea janata are polyphagous and cause mild to severe damage to about 16 forest tree species (Browne, 1968).The attack of A. janata on T. undulata has been notices for the first time from Rajasthan. Larvae of Taragama siva feed on the leaves and growing shoots from July to September. Severe attack has been recorded in the provenance trials of T. undulata. The larvae of hairy catterpillar, Euproctis lunata and E. fraterna feed on the foliage of many dicotyledonous trees viz., Acacia nilotica, Mangifera indica, Morus alba and Zizyphus mauritiana, Tectona grandis, Shorea robusta and Terminalia sp. (Beeson, 1941; Mathur and Singh, 1958) A mild defoliation by this pest has been observed in the provenance trials of T. undulata.The larvae of Atteva fabriciella, a major pest of Ailanthus excelsa through out india, has been recorded to cause moderate infestation to T.undulata from August to October.

\section{Orthoptera (Locusts and Grasshoppers):-}

The order is represented by 14 species which cause mild to moderate defoliation to T. undulata. Out of which only 7 species are recorded to feed on the foliage as potential pests. Five species viz., Schistocerca gregaria, Pyrgomorpha brachycera, Poekilocerus pictus, Hieroglyphus banian and Locusta migratoria are the new pest records on $T$. undulata. The nymphs and adults of Schistocerca gregaria feed on the foliage during August to October at Jodhpur 
and cause moderate infestation to Tecomella seedlings in nurseries and young plantations. Pyrgomorpha brachycera is widely distributed throughout arid and semi-arid areas. It is a general pest in forest nurseries causing damage to the seedlings of many tree species including T.undulata. Poekilocerus pictus, commonly known as Aak grasshopper, is a primary pest of Aak (Calotropis sp.) but the infestation of P.pictus has also been reported on Zizyphus mauritiana, Ficus sp., Citrus sp., Musa sapientum and Carica papaya Gaur (1996) was the first to establish the pest record of P. pictus on T.undulata from arid areas. Nymphs and adults were seen feeding on the foliage, making irregular holes. A mild attack of Hieroglyphus banian has been noticed from August to September on the small saplings of T. undulata in nursery stock. Beeson (1941) has reported H. banian as a severe pest of bamboo forests. Nymphs and adults of Locusta migratoria nibbled the tender and mature leaves, making irregular holes. A mild to moderate attack of this species has been noticed in the young rohida plantations in the experimental area of Arid Forest Research Institute.

\section{Leaf miners:-}

Only two species of leaf miners have been encountered causing damage to $T$. undulata by feeding on foliage through mining operation. Beeson (1941) reported that many more species of the family Cosmopterygidae mine blotches in the living leaves of various tree species and feed on the dead plant refuse. An unidentified species of genus Stagmatophora was observed causing a mild damage in the young seedling of T.undulata in nursery stage. Leucoptera sphenograpta is a generally known micro-lepidoptera which mines the leaf of $T$. undulata. The adult moths are small, narrow-winged with whitish and darker markings. Pale green larvae excavate mines in the soft tissue of the leaves. Heavily mined leaves represent irregular blotches on the lower surfaces. Mild attack of L.sphenograpta has been noticed for the first time on the young seedlings of $T$. undulata.

\section{Sap-sucking insects:-}

Insects with sucking or rasping mouth parts may produces extensive chlorosis, but feeding has little direct effect on yield and quality of crops. Scale insects and hemipteran bugs are the main sapsuckers on T. undulata. Adults and nymphs suck the cell sap of phyllodes and tender leaves and shoots as a result of which affected parts are devitalized, resulting shedding of leaves and drying of the attacked branches. Certain species are implicated in inducing physiological reactions. However, these insects are most noteworthy for their role as vector of plant diseases. They equally attack the succulent parts of young as well as old plants. There are about 13 sap-sucking species belonging to only two orders viz., Hemiptera and Thysanoptera comprising eight different families. The dominant families are Pentatomidae and Thripidae which are represented by two species of each.

\section{Challenges ahead:-}

Forest entomologists must become part of the forest community. There is an urgent need for new biological techniques for forest pest management, and to refine our knowledge on most promising techniques of IPM. Learn more about the technology of large-scale aerial spraying - basically to develop improved strategies for microbial pesticide application. It is a high time to develop multi-disciplinary research teams to address forest insect problems. The need to develop improved damage appraisal systems in order that losses from forest pests may be quantified and that loss statistics can be integrated with provincial inventory statistics to provide regional and national estimates of losses from insects and diseases. There is a need to apply information already known. This is a challenge not only for entomologists, but also for forest managers. Steps to be taken to increase our efforts on the development of preventive techniques of pest management as alternatives to control techniques.

\section{Future Thrust: -}

Strengthening biotechnology in the form of insect-resistant transgenic plants is essentially needed to save our forests from the ravages of insect pests. Greater emphasis is to be given for Integrated Pest Management (IPM) in plant protection, the impact of transgenic on the natural enemy complex at the ecosystem level needs to be addressed. Inputs in pheromone technology have undergone a change in view of the increasing failure of lures to catch insects. These can be classified as (a) bio-informatics and modeling involving development of prediction models based on the knowledge of the biology and ecology of insects which could be used for pest control, and (b) experimental study of insect behaviour requiring detailed study of the response of insects to chemicals (kairomones) using wind tunnel and electro-antennogram techniques which could be used to control pests. The orientation to insect biosystematics studies and drew attention to increased revival of interest in systematic due to increasing demands in biodiversity, especially on its bioinformatics component. It will be of paramount importance in economically important insects relating to agricultural, forestry and health aspects of human life, to not only accumulate the taxonomic information of the above kind, but also develop efficient means of quick information retrieval. 


\section{References:-}

1. Ahmed, Mukhtar. (1992) Insect fauna of Casuarina equisetifolia. Indian J. For. 15: 142-148.

2. Ahmed, S.I. (1982) Studies on the morphology, bionomics, ecology and digestive physiology

3. Ahmed, S.I. (1994) The use of entomopathogenic viruses in forestry: Potential for their use in developing nations.Antenna 18(1): 14-18.

4. Ahmed, S.I. and S.R. Leather. (1994) Suitability and potential of entomopathogenic micro organisms for forest pest- management some points for consideration.Int. J. Pest. Manage. 40 (4): 287-292.

5. Ahmed, S.I. and S. Murugesan. (1995) Achaea janata Linn (Noctuidae: Lepidoptera). A new pest record on Neem-Its management through Nuclear Polyhedrosis Virus.The Indian Forester 121 (1): 63.

6. Ahmed, S.I. and Shivesh Kumar. (1998) Role of natural epizootics of a NPV disease in controlling Prosopis juliflora defoliator, Taragama siva outbreak in north-west Rajasthan. Indian Forester 124 (11): 952-958.

7. Ahmed, S.I; Seema Kumar and Sangeeta Sharma. (1998) Nuclear polyhedrosis of babul defoliator, Taragama siva Lefebvre (Lepidoptera : Lasiocampidae).My Forest 34 (1): 715-721.

8. Ananthakrishnan, T.N. (1984) Biology of Gall Insects. Oxford and IBH Publishing Co. India. 362 pp.

9. Brucher, G.E. (1964) The regulation and control of insects by fungi. Annals of the Entomological Society of Quebec, 9: 30-42.

10. Beeson, C. F. C. (1941) The ecology and control of the forest insects of India and neighbouring countries. Vasant Press, Dehra Dun, India: 1007 pp.

11. Browne, F.G. (1968) Pests and Diseases of Forest planatation trees. Claredon Press. Oxford: 1231 pp.

12. Brucher, G.E. (1964) The regulation and control of insects by fungi. Annals of the Entomological Society of Quebec, 9: 30-42.

13. Coulson, N Robert and J.A Witter. (1984) Forest Entomology. Ecology and Management. John Wiley and Sons. New York: 669 pp.

14. Cunningham, J. C. (1985) Status of viruses as biological agents for spruce bud worms. Proc. Symp. Microbial Control of Spruce Budworms and Gypsy moths. Windsor Locks, CT, USDA-GTR 100: 175 pp.

15. David, B.V and T.R. Subramaniam. (1976) Studies on some Indian Aleyrodidae. Rec. Zool. Surv. India,70 : 133-233.

16. Dresner, E. (1949) Culture and use of entomogenous fungi for the control of insect pests. Contribution of the Boyce Thompson Institute, 15: 319-335.

17. De loach, C.J and J.P. Cuda. (1994) Host range of the mesquite cut worm, Melipotis indomita (lepidoptera : Noctuidae), a potential biocontrol agent for mesquite (Prosopis spp.,).In Biological control : Theory and Application in management U.S.A 4 (1): 38-44.

18. ESC. (1986) Microbial insecticide in canada:their registration and use in agriculture, forestry and public and animal health. A report prepared by the special committee of the science

19. Ganguli, B.N ; R.N. Kaul and K.T.N. Nambiar. (1964) Preliminary studies on a few top feed species. Ann. Arid. Zone 3 (2): 33-37.

20. Johnson, C.D. (1983) Handbook on seed insect of Prosopis species. Ecology, Control and Identification of seed infesting insects of New world Prosopis (Leguminosae).FAO Publication. 55 pp.

21. Johnson, C.D and D.H. Siemens. (1997) Distribution oviposition guilds, behaviour and new host records from Latin America for Algarobious bridwell sartobruchus Kingsolver and Pseudopachymering spirinpes Erishson (Coleoptera: Bruchidae). Coleopterists Bulletin 57(1): 37-42.

22. Kumar Seema; S.I. Ahmed and Sahdev Kumar. (1994) Annotated list of insect pests of forest trees of arid and semi arid regions Rajasthan and Gujarat. Oikoassay 11(1,2): 5-9.

23. Mani, M.S. (1964) Ecology of Plant Galls. Dr. W. Junk, The Haque. 434 pp.

24. Mathur, R.N and B. Singh. (1960) A list of insect pests of forest plants in India and the adjacent countries.Indian Forest Bulletin 171: 1-130.

25. Murugesan, S and Shivesh Kumar. (1996) New record and damage of flower thrips in the introduced tree species of arid region.Indian Forester 122 (9): 854-855.

26. Otvos, I.S and B.H. Moody. (1978) The spruce bud worm in New found land: history, status and contol. Canadian Forest Sevice St. Johns Information Report, N X 150: 76 pp.

27. Patel R M, C B Patel and H N Vyas 1977 Record and some observations on local milky

28. disease in whitegrubs ( Holotrichia sp. ,Near consanguinea Blanch.) in India. Indian J. Ent.

29. 39 181-182

30. Parihar, D.R. (1978) Field observations on the nature and extent of damage by Indian termites and their control. Ann. of Arid Zone 17 (2): 192-199.

31. Parihar, D.R. (1980) termite problems in desert planataions. Ann. of Arid Zone 19 (2): 329- 339. 
32. Parihar, D.R. (1987) Grasshopper pests of grazingland vegetation and their management in Indian Desert. CAZRI Publication $29: 56 \mathrm{pp}$.

33. Parihar, D.R. (1993) Insect fauna of Khejri, Prosopis cineraria of arid zone.Indian Journal Forestry 16: 132137.

34. Parihar, D.R and A.V. Kampantzov. (1997) Faunal diversity and associated predators and parasites of wood boring Coleoptera of Rajasthan Desert. Ann. of Arid Zone 36 (4): 367-373.

35. Parihar, D.R and M.P. Singh. (1998) Insects associated with Prosopis cineraria in arid western Rajasthan, India. In Prosopis specoes in the arid and semi arid zones of India, edited by J.C. Tewari, N.M. Pasiecznik, L.N. Harsh and P.J.C. Harris. Published by Prosopis society of India and the Henry Double day Research Association:99-102 pp.

36. Pillai Madhavan S R and Gopi K C 1990 Seasonal drying up of the shoots of neem

37. (Azadirachta indica A.Juss) and important insect pest associated with it My Forest 26 33-50.

38. Puri G S, S K jain S K Mukherjee, Shanti Sarup and N N Kotwal 1964 Flora of Rajasthan. Rec. Bot. Survey of India 19.1-159.

39. Singh, M.P. (1998) Injurious hexapoda associated with Prosopis. In Prosopis specoes in the arid and semi arid zones of India. edited by J.C. Tewari, N.M. Pasiecznik, L.N. Harsh and P.J.C. Harris. Published by Prosopis society of India and the Henry Double day Research Association:105-108 pp.

40. Satyavir (1996) Bruchid infestation of leguminous trees in the thar desert. Tropical Science 36 (1): 11-13.

41. Sen-Sarma, P.K. (1986) Some important problems of forest insect pests and research programmes. Second Forestry Conference Dehra Dun :879-883.

42. Sen-Sarma, P.K and M.L. Thakur (1986) Termite problems in fodder and fuel wood planatation and their management in India. Proc. Symp. Afforestation of Wastelands (28-30 May, 1986). Dehradun.; 15 pp.

43. Sundararaj, R and S. Murugesan (1996) Occurence of Acaudaleyrodes rachipora (Singh) (Aleyrodidae: Homoptera) as a pest of some important forest trees in Jodhpur (India).Indian J. Forestry.19(3): 247-248.

44. Sacchan, J.N and S.K.Pal. (1972) Some observations on the gall formation in Prosopis cineraria. Ann. of Arid Zone. 12(1,2):103-104.

45. Sen-Sarma, P.K. (1986) Some important problems of forest insect pests and research programmes. Second Forestry Conference Dehra Dun :879-883.

46. Sen-Sarma, P.K. (1986) Some important problems of forest insect pests and research programmes. Second Forestry Conference Dehra Dun :879-883.

47. Sharma, S.K and R.K. Gupta. (1981) Effect of seasonal lopping on the top feed (loong) production and gowth of prosopis cineraria (Linn.) Druce. Indian J. Forestry. 4(4): 253-255.

48. Suresh Kumar. (1985) Bio-ecology of the green lacewing, Chrysopa scalestes Banks.

49. Tewari, D.N. (1992) Monograph on Neem (Azadirachata indica A Juss). International Book Distributor, Dehra Dun: 279 pp.

50. Ueckert, D. N and H.A. Wright. (1974) wood boring insect infestations in relation to Mesquite control Practices.J. Range. Management 27 (5): 383-386.

51. Verma, S.K and S. Vir. (1995) Field insect pests of Rohida (Tecomella undulata) in Arid Zones of Rajasthan. Ann. Arid Zone 34:54-55.

52. Yousuf, M and Meeta Gaur. (1998 a)Some note worthy insect pests of Prosopis juliflora from Rajasthan. In Prosopis specoes in the arid and semi arid zones of India. edited by J.C. Tewari, N.M. Pasiecznik, L.N. Harsh and P.J.C. Harris. Published by Prosopis society of India and the Henry Double day Research Association:91$94 \mathrm{pp}$.

53. Yousuf, $\mathrm{M}$ and Meeta Gaur. (1998 b) Record on complete defoliation and host range of Taragama siva Lefebvre (Lepidoptera: Lasiocampidae). Bioscience Research Bulletin.12(2):85-88.

54. Klapwilk, M., Bylund, H., Schroeder and Bjorkman (2016). Forest management and natural biocontrol of insect pests. Forestry:An International Journal of Forest Research. 89 (3): 253-262. 